GEOGRAFICKÝ ČASOPIS / GEOGRAPHICAL JOURNAL 73 (2021) 1, 83-97

DOI: https://doi.org/10.31577/geogrcas.2021.73.1.05

\title{
DYNAMIKA HISTORICKÝCH ŠTRUKTÚR POLNOHOSPODÁRSKEJ KRAJINY, PRÍPADOVÁ ŠTÚDIA: VYBRANÁ ČASŤ KOPANIČIARSKEHO REGIÓNU MYJAVA
}

\author{
Filip Moravčík*, Alexandra Benová* \\ * Univerzita Komenského v Bratislave, Prírodovedecká fakulta, Katedra fyzickej geografie a geoinformatiky, \\ Ilkovičova 6,84215 Bratislava, moravcik48@uniba.sk, alexandra.benova@uniba.sk
}

\begin{abstract}
Dynamics of historical structures of agricultural landscape, case study: Part of the scattered settlement of Myjava region

The historical structures of the agricultural landscape are important elements of biodiversity and landscape diversity. The aim of the paper is to identify subtypes and dynamics of historical structures within a selected part of the Myjava region in the period from 1957 to 2017. Five different map sources and retrospective comparison of the individually interpreted maps (approaching from newest to oldest) were used. The area is specific due to the occurrence of a scattered settlement. Attention is also paid to the impact of various socio-economic events and the analysis of the distance from the economic centre of the area - the town of Myjava. During the observed period, a decay of historical structures was recorded, the most significant in the years 1983 to 2003 and also a reduction in the average size of the areas of interest. Processes of extensification of agriculture, intensification of agriculture and urbanization were identified. Using distance analysis, a larger decay was determined in zones that were further away from Myjava. Collectivization of agriculture during the 1970s and 1980s or political changes during 1990s and 2000s did not have a radical influence and the area has retained its typical character to these days.
\end{abstract}

Key words: historical structures of agricultural landscape, scattered settlement, collectivization of agriculture, retrospective analysis, Myjava region

\section{ÚVOD}

Súčasný stav krajiny je výsledkom pôsobenia mnohých faktorov, ktoré majú za následok pretváranie pôvodného obrazu krajiny. Aj napriek ich značnému vplyvu možno stále identifikovat' výskyt konkrétnych jadrových území pôvodných pol'nohospodárskych krajinných štruktúr, ktoré častokrát predstavujú významné centrá krajinnej diverzity (Huba et al. 1988, Slámová 2013 a Špulerová et al. 2017). Tieto územia môžeme označit' ako historické štruktúry pol'nohospodárskej krajiny (HŠPK), pričom vd'aka svojej nezastupitel'nej úlohe v krajine predstavujú zaujímavú oblast' výskumu. Pre výskum HŠPK je dôležité sledovat' najmä zmeny krajinnej pokrývky.

HŠPK predstavujú subtyp štruktúr krajiny, ktoré sú charakterizované ako hmotná nehnutel'ná čast' dedičstva (Huba 1988). Zároveň sú súčast'ou sekundárnej krajinnej štruktúry a následne aj obrazom určitého vývoja využitia krajiny, ktorý je tiež akýmsi odrazom toho, ako sa spoločnost' vysporiadala s rozličnými, najmä spoločensko-politickými vplyvmi. Areály HŠPK sú zväčša extenzívne obhospodarované lúky a pasienky, resp. polia. Taktiež sú sem zarad'ované aj ovocné sady a vinohrady spolu s opustenými, a v súčasnosti už nevyužívanými plochami, na ktorých je možné dokumentovat' pomerne nízky stupeň sukcesie. Ide o areály, kde nebol identifikovaný proces intenzifikácie a ktoré taktiež podliehajú definícii podl'a nasledovných znakov: zachovanie pôvodnej maloplošnej štruktúry areálov; (alebo/ 
a) nezmenený spôsob využívania počas kolektivizácie v období socializmu; (alebo/ a) zachovanie agrárnych foriem reliéfu; (alebo/a) zachovanie znakov využívania tradičných technológií, ktoré slúžia na obhospodarovanie areálov (Špulerová et al. 2017). Tieto areály sú častokrát vystavované degradácii a nasledovnému pustnutiu a chátraniu (Huba 2004), pričom značný negatíyny vplyv na ich zachovanie má územný rozvoj a intenzívne pol'nohospodárstvo (Špulerová a Petrovič 2011).

Analýzu opustenej tradičnej pol'nohospodárskej krajiny ponúkajú vo svojej práci Lieskovský et al. (2015), pričom autori sa venujú aj problematike vplyvu vzdialenosti od regionálneho centra oblasti. Slámová et al. (2013) ponúkajú metódy identifikácie HŠPK v horských a podhorských oblastiach. Dôraz je kladený najmä na reliéf a kategorizáciu do rozličných typov krajiny. Problematika typizácie historických štruktúr je podrobne rozoberaná v príspevku Špulerovej et al. (2012), ktorý prináša nový postup v súvislosti s typizáciou jednotlivých areálov HŠPK. Špulerová et al. (2017) kladú dôraz na detailné hodnotenie HŠPK na území Slovenskej republiky. Súčast'ou príspevku je aj typizácia HŠPK s podrobnou charakteristikou, ktorú sme využili ako metodické východisko. Podrobná metodika výskumu HŠPK, ktorá bola využitá aj v našom prípade, je charakterizovaná v príspevku Dobrovodskej et al. (2014), pričom táto zohl'adňuje spôsob hospodárenia s pôdou a následne definuje štyri základné typy HŠPK na báze prítomnosti rozptýleného osídlenia, vinohradov, resp. ovocných sadov, a následne s nimi súvisiace subtypy. Analýze historických štruktúr sa venuje aj značné množstvo zahraničných autorov. Napríklad Sereni (1997) ponúka komplexnú analýzu pol’nohospodárskej krajiny na území Talianska so zretel'om na zachované historické štruktúry. Problematike historických štruktúr v oblasti Talianska sa venujú aj práce autorov Agnoletti (2006 a 2013) a Agnoletti et al. (2011). Dynamikou rozličných biotopov v rámci historických štruktúr v podmienkach Dánska sa zaoberajú Agger a Brandt (1988). Autorka Crews-Meyer (2004) rieši historické štruktúry naviazané na pol'nohospodársku krajinu v regióne Thajska. Spooner et al. (2004) sa zaoberajú pol'nohospodárskou krajinou Austrálie a jej vývojom v čase.

Záujmové územie, na ktorom bol v našom prípade realizovaný výskum, je charakteristické roztrateným osídlením predstavujúcim osobitý fenomén so svojráznymi štruktúrami a typickou stavebnou kultúrou (Hanušin a Lacika 2018), a to aj napriek skutočnosti, že jeho vznik bol častokrát iba následkom dosídl'ovania existujúcej anekumény v odl'ahlejších častiach katastrálnych území (Huba 1989). Petrovič (2005) sa zaoberal členením jednotlivých oblastí s roztrateným osídlením v rámci Slovenska. Problematike roztrateného osídlenia sa venovali napr. Lauko (1985), Huba (1997), Spišiak (1998) či Petrovič (2002a a 2002b). Téma roztrateného osídlenia a jeho postupnej transformácie $\mathrm{v}$ regióne Myjavy bola riešená autormi Lauko (1990 a 1999) a Lauko a Nemček (1998). Moravčík a Benová (2020) riešili problematiku výskytu krajinných prvkov na území myjavských kopaníc.

Ciel'om príspevku je charakterizovat' dynamiku HŠPK vo vybranej časti kopaničiarskeho regiónu Myjava v období rokov 1957 až 2017 na základe rôznych mapových podkladov a taktiež identifikovat' výskyt jednotlivých subtypov HŠPK podl'a metodiky Špulerovej et al. (2017). Pozornost' je venovaná aj výskytu areálov HŠPK v súvislosti so vzdialenost'ou od ekonomického centra danej oblasti, ktoré predstavuje okresné mesto Myjava. Okrem priestorového aspektu je zohl'adnený aj aspekt časový, a to pomocou identifikácie možného vplyvu rôznych spoločenskoekono-mických míl'nikov na výskyt HŠPK. 


\section{ZÁUJMOVÉ ÚZEMIE}

Záujmové územie $\mathrm{s}$ rozlohou 21,46 $\mathrm{km}^{2}$ sa nachádza v okrese Myjava a zasahuje do štyroch katastrálnych celkov, predovšetkým do Starej Myjavy a Brestovca, okrajovo aj do Myjavy a Poriadia (obr. 1). Vol'ba územia sa viazala na výskyt HŠPK roztrateného osídlenia. Záujmová oblast' má typický kopaničiarsky ráz a v území sa doposial' nerealizoval podrobný výskum HŠPK.

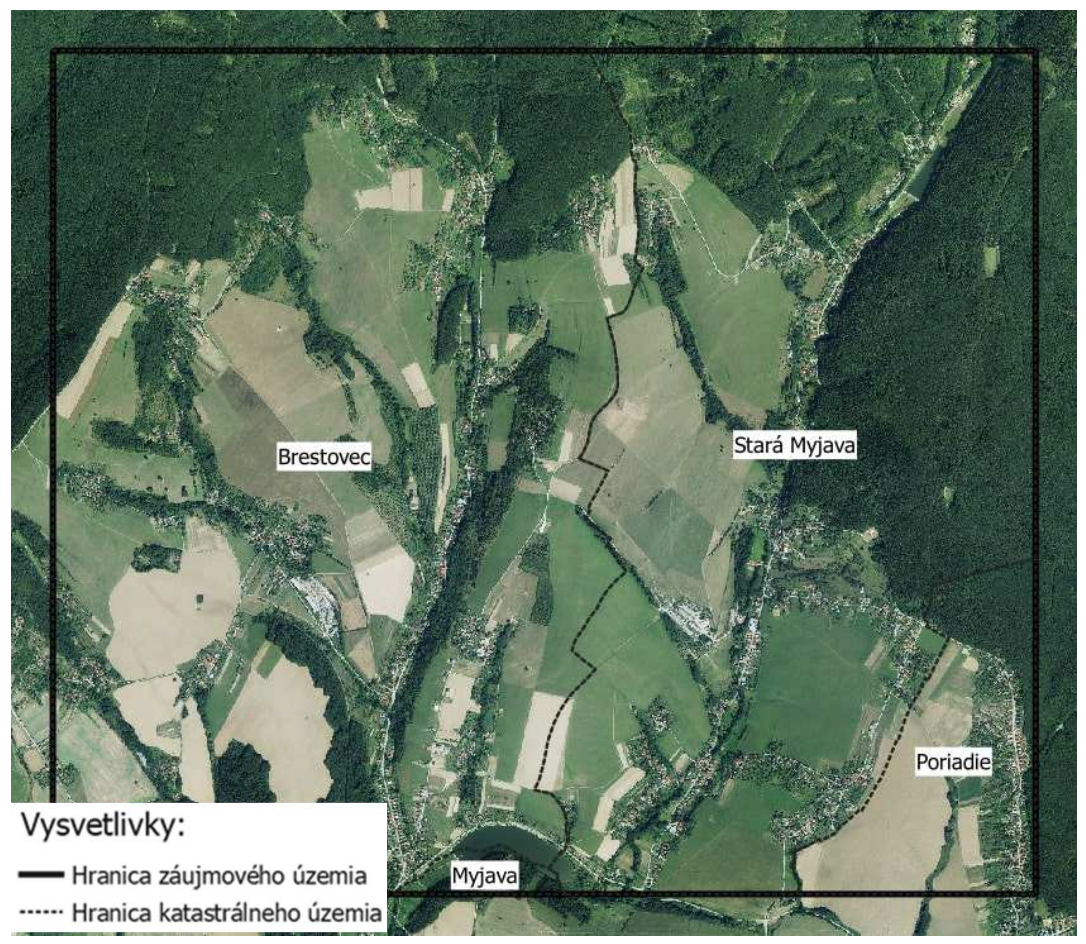

Obr. 1. Vyhraničenie záujmového územia

Zdroj: WMS Digitálna ortofotomozaika 2017; C ÚGKK, MPaRV SR, GKÚ, NLC Zvolen.

\section{METÓDY A ÚDAJE}

Vizuálna interpretácia jednotlivých mapových podkladov (Vojtko a Reichwalder 2016) je základnou metódou použitej retrospektívnej analýzy. Východiskový podklad predstavuje najnovší podklad, s ktorým je porovnávaný časovo najbližší starší podklad, a s ním následne d’alší v poradí (Kaňuk et al. 2015).

V prípade použitia historických máp je potrebné vopred zvážit' charakter, obsahovú bohatost', mieru generalizácie a účel konkrétneho diela. Falt’an et al. (2018) uvádzajú, že mapové zdroje sú vhodným podkladom pre výskum zmien krajiny. Výskum zmien v krajine na základe historických mapových podkladov realizovali aj Brůna et al. (2002), pričom vhodnost' použitia týchto podkladov uvádzajú aj Cajthaml a Krejčí (2008). Analýza zmien v krajine využitím ortofotomáp je aplikovaná autormi častejšie, pričom sa ňou zaoberali napr. Čerňanský et al. (2003), Čerňanský a Kožuch (2004), Stanková (2007) a Falt’an et al. (2018). V našom prípade sme použili podklady: Digitálna ortofotomozaika (DO) z roku 2017 (ÚGKK SR 
2020), Základná báza údajov pre geografický informačný systém (ZBGIS) z roku 2007 (ÚGKK SR 2007), Digitálna ortofotomapa Slovenskej republiky (DGO SR) z roku 2003 (Geodis Slovakia a Eurosense 2003), Základná mapa Slovenskej republiky (ZM SR) z roku 1983 (SAŽP 2020) a Topografická mapa v GaussKrügerovom zobrazení (TM G-K) z roku 1957 (SAŽP 2020). Mapy TM G-K a ZM SR boli vyhotovené v mierke 1:10 000, pričom ich interpretácia bola uskutočnená pomocou mapových kl'účov: TM G-K (ÚSGK 1959), ZM SR (SSGK 1972). TM G -K, ZM SR a DO boli použité vo forme WMS vrstiev (SAŽP 2020 a ÚGKK SR 2020). DGO SR bola využitá vo forme rastrovej údajovej štruktúry (.jpg), údaje ZBGIS vo vektorovej údajovej štruktúre (.shp). Diapazón údajov mal zachytit’ rôzne spoločenské míl'niky, ako napr. kolektivizácia pol’nohospodárstva (2. polovica 20. storočia), zmena politického režimu (1989), vstup SR do EÚ (2004).

Spracovanie vstupných údajov bolo realizované procesom vektorizácie (Cajthaml a Krejčí 2008 a Cajthaml 2013), ktorý bol uskutočnený na jednotlivých podkladoch, s následnou rekognoskáciou územia. Rozloha minimálnej mapovacej jednotky (Husár 1996 a Mičietová a Kožuch 2008) bola stanovená na 90 m². Následne boli určené záujmové triedy Corine Land Cover (CLC) z hl'adiska identifikácie HŠPK, a to orná pôda, trvalé trávne porasty (lúky a pasienky) a ovocné sady. Ked’že $\mathrm{v}$ rámci sledovaného územia bola zaznamenaná prítomnost' roztrateného osídlenia a zároveň v oblasti existuje predpoklad výskytu HŠPK, boli záujmové tie subtypy HŠPK, ktoré sú naviazané na roztratené osídlenie. Podl’a Špulerovej et al. (2017) sú to subtypy s dominanciou sadov, dominanciou trvalých trávnych porastov, výskytom mozaiky ornej pôdy a trvalých trávnych porastov a výskytom mozaiky ornej pôdy, trvalých trávnych porastov a sadov. Areál sme považovali za zachovanú HŠPK, ak sa v nezmenenej podobne vyskytoval na jednotlivých použitých mapových podkladoch (od roku 1957 po rok 2017). Vyhodnotenie bolo realizované na základe vizuálnej interpretácie podkladov pomocou dostupných mapových kl'účov a rozhodnutia interpretátora, pričom určujúca bola prítomnost záujmových tried CLC a ich vzájomná kombinácia. V prípade sledovania dynamiky HSPK boli zaznamenávané plošné zmeny jednotlivých subtypov medzi mapovými podkladmi s následným vyhodnotením vo forme úbytkov. V prípade, že areál zostal v nezmenenej podobe, bol nad’alej považovaný za HŠPK. Avšak, ak bola zadokumentovaná zmena záujmového areálu z hl'adiska zastúpenia jednotlivých tried CLC, tak bol konkrétny areál osobitne posudzovaný na základe zistenej zmeny, čoho výsledkom mohol byt' zánik daného areálu ako HŠPK alebo zmena subtypu HŠPK. Po vytypovaní záujmových plôch bolo realizované porovnávanie areálov medzi jednotlivými podkladmi. Taktiež bola vykonaná vzdialenostná analýza výskytu areálov HŠPK, pričom ako východiskový bod bol zvolený Kostol sv. Stefana Uhorského v centrálnej časti Myjavy, ktorá je okresným mestom a predstavuje ekonomické centrum danej oblasti nachádzajúce sa $v$ tesnej blízkosti záujmového územia. Pri realizácii boli použité technologické prostredia QGIS vo verzii 3.10 a ArcMap vo verzii 10.6 .

\section{VÝSLEDKY}

Na všetkých použitých mapových podkladoch boli identifikované štyri subtypy HŠPK, ktoré sú naviazané na roztratené osídlenie v zmysle Špulerovej et al. (2017).

V prípade najstaršieho použitého mapového podkladu (TM G-K), ktorý charakterizuje stav územia z roku 1957 (obr. 2.), bola identifikovaná celková rozloha 
HŠPK na úrovni 290,08 ha. Najväčšiu plošnú rozlohu nadobudli HŠPK s dominanciou sadov - viac ako 156 ha. Naopak, najmenšia rozloha bola zadokumentovaná v prípade HŠPK s mozaikou ornej pôdy a trvalých trávnych porastov (TTP), ktorých rozloha predstavovala takmer 19 ha. Priestorové rozloženie HŠPK v rámci územia je pomerne rovnomerné. Poradie jednotlivých subtypov HŠPK z hl'adiska kvantifikácie na základe plošného zastúpenia je uniformné v prípade všetkých mapových podkladov, ked’že dominantné postavenie zaujíma subtyp HŠPK s prevahou sadov a marginálny výskyt je zaznamenaný v prípade HŠPK s výskytom mozaiky polí a TTP.

Nasledujúcim analyzovaným podkladom bola ZM SR, ktorá zobrazuje stav štruktúr z roku 1983 (obr. 3.). HŠPK zaznamenali celkovú rozlohu viac ako 266 ha, pričom pokles oproti predchádzajúcemu obdobiu predstavoval 23,28 ha $(8,03 \%)$. Z hl'adiska plošného zastúpenia mal opät' dominantné postavenie subtyp HŠPK s prevahou sadov - rozloha viac ako 144 ha. Naproti tomu HŠPK, tvorené mozaikou ornej pôdy a TTP, nadobudli najmenšiu rozlohu - iba viac ako 16 ha. Najväčší absolútny plošný úbytok dosiahol subtyp HŠPK $\mathrm{s}$ dominanciou sadov, a to na úrovni 11,45 ha $(7,33 \%)$. Najväčší relatívny úbytok zaznamenal subtyp s dominanciou výskytu mozaiky polí a TTP - 2,66 ha (14,00\%). Dynamika úbytkov HŠPK dosiahla v rokoch 1957 - 1983 úroveň 0,90 ha/rok, pričom zmeny mali charakter najmä intenzifikácie pol'nohospodárstva a urbanizácie. Úbytky nastali najmä vo východnej časti územia (katastrálne územie obce Stará Myjava), avšak aj napriek tejto skutočnosti sa priestorové rozloženie subtypov HŠPK javí ako rovnomerné.

DGO SR predstavuje podklad, pomocou ktorého je možné rekonštruovat' stav HŠPK z roku 2003 (obr. 4.). Celková rozloha všetkých subtypov HŠPK dosiahla viac ako 170 ha, čo predstavuje pokles v porovnaní s predchádzajúcim obdobím o takmer 96 ha $(35,96 \%)$. Ide o najväčší zaznamenaný úbytok medzi sledovanými obdobiami.

Rozloha subtypu s dominanciou sadov klesla pod 92 ha (pokles o takmer 53 ha, čo predstavuje 36,57 \%) a ide o najvyšší absolútny úbytok v danom období. Rozloha plôch s mozaikou polí, TTP a sadov klesla pod 43 ha (úbytok o takmer 29,65 ha, resp. 40,92\%). Úbytky boli zaznamenané v rámci celého sledovaného územia s výnimkou jeho juhovýchodnej časti. Dynamika úbytkov v období rokov 1983 2003 nadobudla hodnotu až 4,80 ha/rok, pričom boli identifikované procesy intenzifikácie a extenzifikácie pol'nohospodárstva, a taktiež proces rozširovania zástavby. V tomto období možno pozorovat' už určité diskrepancie v rovnomernosti priestorového rozloženia areálov HŠPK, ked’že zachované záujmové plochy sú lokalizované vo väčšej miere v juhovýchodnej a severnej časti sledovaného územia.

Ďalším analyzovaným podkladom boli údaje ZBGIS, pomocou ktorých vieme rekonštruovat' stav HŠPK z roku 2007 (obr. 5.). V tomto období bol identifikovaný celkový pokles rozlohy HŠPK na úrovni takmer 6 ha $(3,39 \%)$, pričom celková rozloha bola viac ako 165 ha. HŠPK s dominanciou sadov dosiahli rozlohu menšiu ako 90 ha, ked'že zaznamenali úbytok o takmer 2,5 ha, čo predstavuje 2,66 \%. Najvyšší relatívny úbytok dosiahol subtyp s výskytom mozaiky polí a TTP - 1,15 ha $(9,14 \%)$. Najmenší úbytok oproti predchádzajúcemu obdobiu bol identifikovaný v prípade subtypu s dominanciou TTP - iba na úrovni 0,37 ha $(1,57 \%)$. Jednotlivé úbytky nastali najmä v južnej časti územia. Naproti tomu, v severnej časti územia zostali jednotlivé areály HŠPK zachované. Dynamika úbytkov zaznamenala medzi rokmi 2003 - 2007 úroveň 1,45 ha/rok, zároveň boli dokumentované procesy ex- 
tenzifikácie pol'nohospodárstva a rozširovania zástavby. Priestorové rozloženie areálov si zachovalo charakter $\mathrm{z}$ predchádzajúceho obdobia s prevahou výskytu v rámci juhovýchodnej a severnej časti.

Záverečným hodnoteným podkladom bola DO, ktorá zobrazuje stav územia v roku 2017 (obr. 6.). Súhrnná rozloha HŠPK bola viac ako 152 ha, čo predstavuje pokles o 12,5 ha $(7,67 \%)$. Najväčší absolútny úbytok zaznamenal subtyp, kde dominovali ovocné sady, a to o viac ako 7,5 ha $(8,49 \%)$ - rozloha takmer 82 ha. Najväčší relatívny úbytok bol v prípade subtypu s dominanciou mozaiky polí, TTP a sadov $-4,52$ ha $(11,02 \%)$. Úbytky boli rozložené pomerne rovnomerne v rámci územia, okrem jeho juhozápadnej časti. Dynamika úbytkov mala v období 2007 2017 hodnotu 1,27 ha/rok, identifikované boli procesy extenzifikácie pol'nohospodárstva a rozširovanie zástavby. V priestorovom rozložení subtypov HŠPK možno pozorovat' trend vyskytujúci sa už aj v rámci dvoch predchádzajúcich období, ked'že je možné identifikovat' výraznejš́i výskyt areálov HŠPK v juhovýchodnej a severnej časti územia.

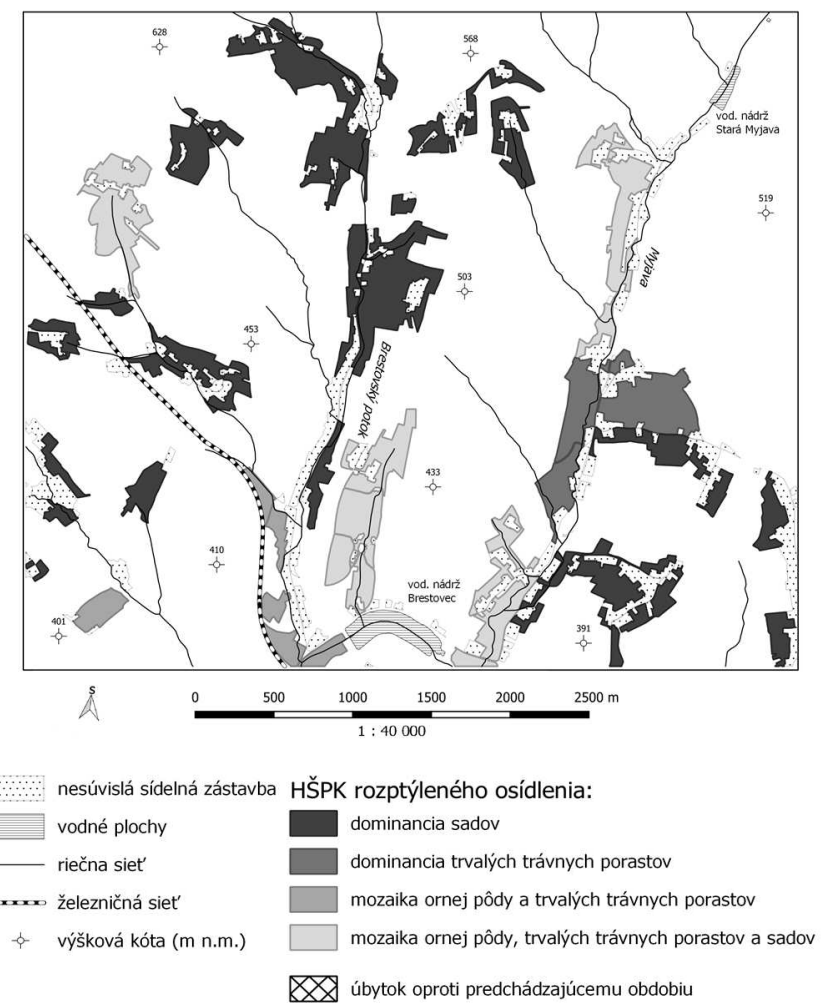

Obr. 2. Historické štruktúry pol’nohospodárskej krajiny v roku 1957

Zdroj: SAŽP (2020). 


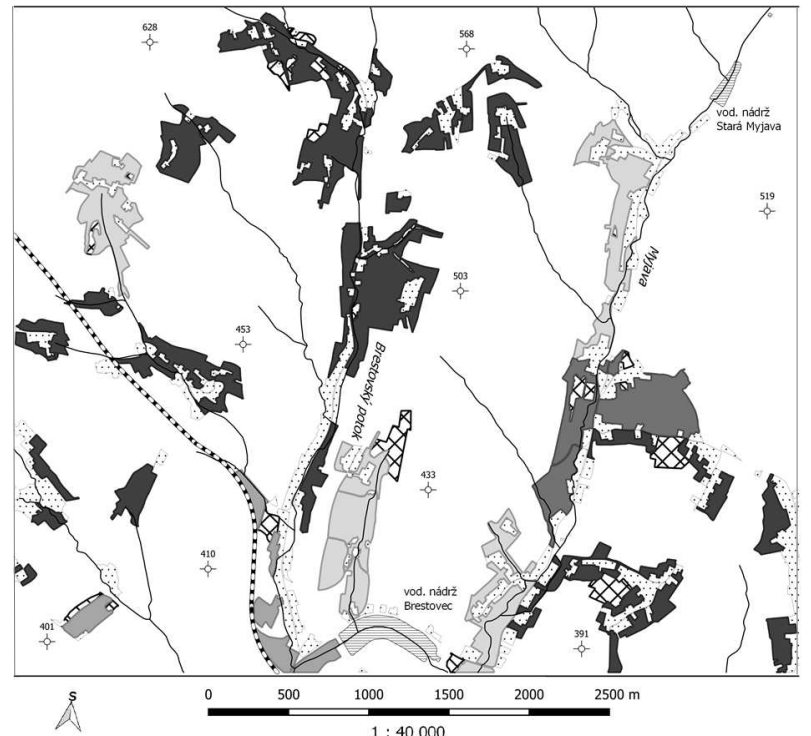

Obr. 3. Historické štruktúry pol'nohospodárskej krajiny v roku 1983 (pozri vysvetlivky k obr. 6) Zdroj: SAŽP (2020).

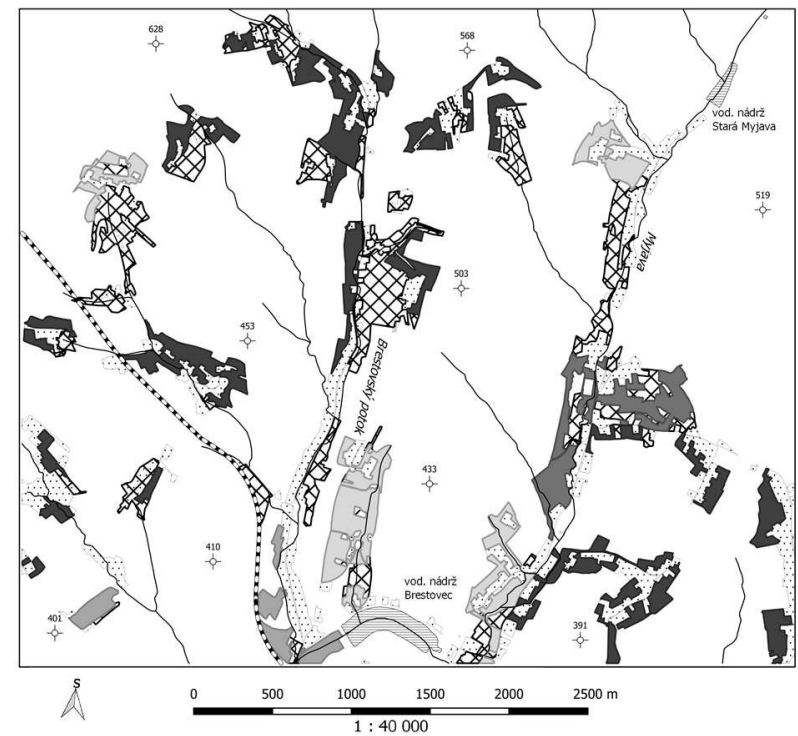

Obr. 4. Historické štruktúry pol’nohospodárskej krajiny v roku 2003 (pozri vysvetlivky k obr. 6)

Zdroj: Geodis Slovakia a Eurosense (2005). 


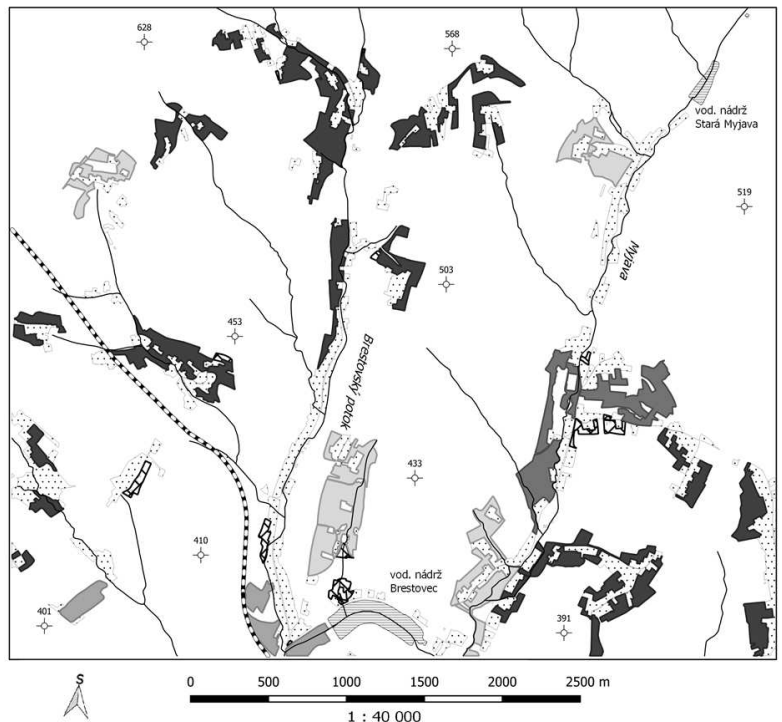

Obr. 5. Historické štruktúry pol’nohospodárskej krajiny v roku 2007 (pozri vysvetlivky k obr. 6) Zdroj: Zdroj: ÚGKK SR (2007)

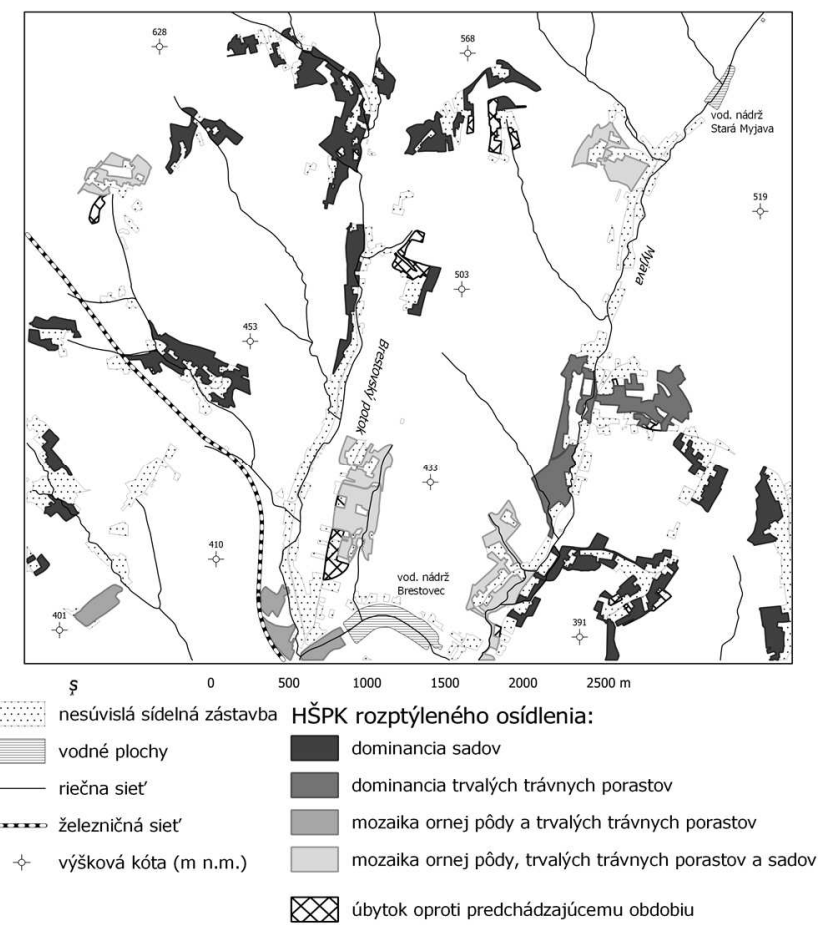

Obr. 6. Historické štruktúry pol’nohospodárskej krajiny v roku 2017 Zdroj: ÚGKK SR (2020). 
Z hl'adiska porovnania celého sledovaného obdobia rokov 1957 - 2017 možno určit' pokles rozlohy areálov HŠPK na úrovni viac ako 137 ha (obr. 7.). Subtypy HŠPK, v spojitosti s percentuálnym podielom na rozlohe všetkých areálov HŠPK, nadobúdali hodnoty v rozmedzí 53,65 \% (DO) až 54,25 \% (ZM SR) v prípade subtypu, kde dominovali sady. HŠPK s dominanciou TTP zaznamenali percentuálne zastúpenie v rozmedzí 12,43 \% (TM G-K) až 14,93 \% (DO). Podiel subtypu s výskytom mozaiky ornej pôdy a TTP sa pohyboval v rozmedzí 6,12 \% (ZM SR) až 7,49 \% (DO). Podiel výskytu mozaiky ornej pôdy, TTP a sadov bol zaznamenaný na úrovni od 23,92 \% (DO) do 27,18\% (TM GK).

Zachované HŠPK zaberajú 152,41 ha, čo predstavuje 12,62 \% zo súhrnnej rozlohy pol'nohospodárskej pôdy $\mathrm{v}$ rámci sledovaného územia, ktorá je na úrovni 1 207,32 ha. Dynamika úbytkov medzi jednotlivými obdobiami zaznamenala vrchol v rokoch 1983 až 2003 (obr. 8).

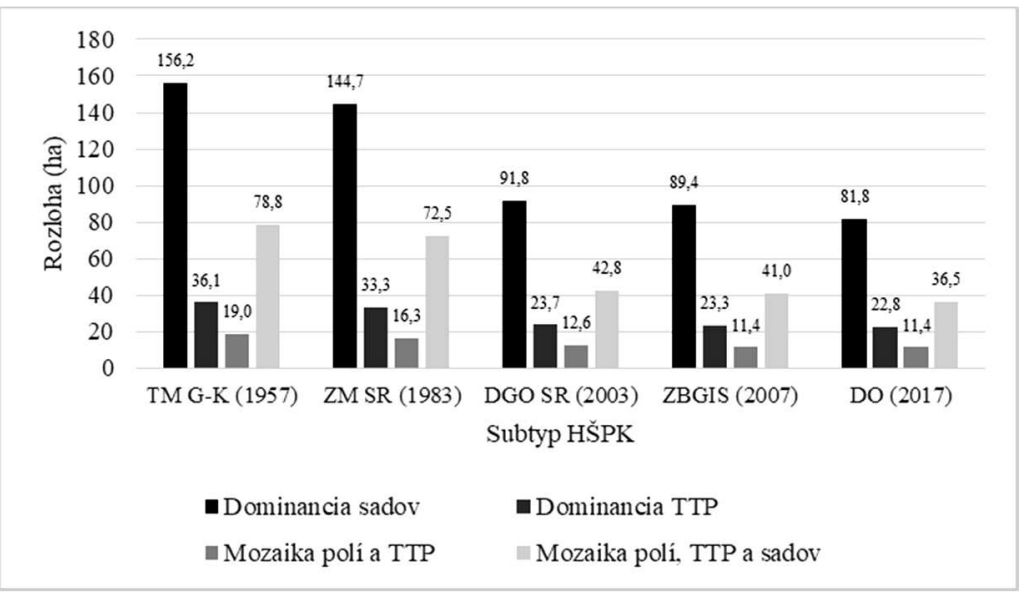

Obr. 7. Rozloha (v ha) historických štruktúr pol'nohospodárskej krajiny počas sledovaného obdobia (1957 - 2017)

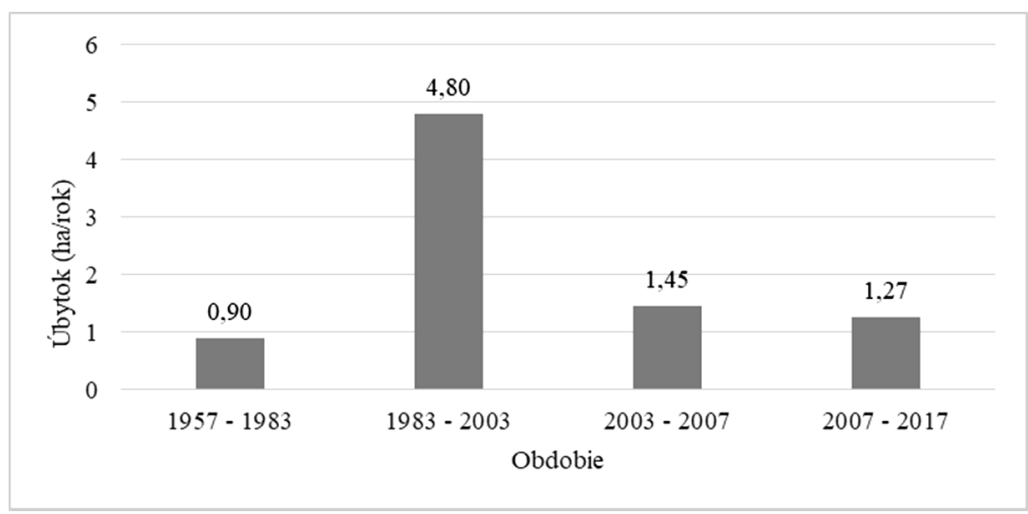

Obr. 8. Dynamika úbytkov historických štruktúr pol’nohospodárskej krajiny počas sledovaného obdobia 1957 - 2017 (ha/rok) 
Vzdialenostná analýza bola uskutočnená pre roky 1957 a 2017 (tab. 1), pričom boli vytvorené tri zóny na základe vzdialenosti od okresného mesta Myjava a celkového charakteru skúmaného územia: zóna 1 - vzdialenost' do $3 \mathrm{~km}$, zóna 2 vzdialenost' 3 až $5 \mathrm{~km}$ a zóna 3 - vzdialenost' viac ako $5 \mathrm{~km}$. Najväčšia rozloha HŠPK bola identifikovaná v oblasti, ktorá je vzdialená 3 až $5 \mathrm{~km}$ od okresného mesta. Naopak, najmenšia rozloha areálov bola určená v oblasti do $3 \mathrm{~km}$.

Tab. 1. Absolútna a relatívna rozloha areálov HŠPK $v$ rámci jednotlivých zón na základe vzdialenostnej analýzy od okresného mesta Myjava v rokoch 1957 a 2017

\begin{tabular}{crrrrrr}
\hline \multirow{2}{*}{ Mapový podklad } & \multicolumn{2}{c}{ Zóna 1 } & \multicolumn{2}{c}{ Zóna 2 } & \multicolumn{2}{c}{ Zóna 3 } \\
\cline { 2 - 7 } & \multicolumn{1}{c}{ ha } & $\%$ & \multicolumn{1}{c}{ ha } & \multicolumn{1}{c}{$\%$} & \multicolumn{1}{c}{ ha } & $\%$ \\
\hline TM G-K (1957) & 15,93 & 5,49 & 169,74 & 58,51 & 104,42 & 36,00 \\
DO (2017) & 9,08 & 5,95 & 97,55 & 63,98 & 45,85 & 30,07 \\
\hline
\end{tabular}

V súvislosti s priemernou rozlohou areálov HŠPK (tab. 2) možno pozorovat' klesajúci trend pri všetkých identifikovaných subtypoch HŠPK. Najväčšiu priemernú rozlohu zaznamenal subtyp HŠPK s dominanciou TTP, naopak najmenšie hodnoty priemernej rozlohy boli identifikované v prípade subtypov s výskytom mozaiky polí a TTP.

Tab. 2. Priemerná rozloha areálov HŠPK počas sledovaného obdobia 1957 - 2017 (ha)

\begin{tabular}{cccccc}
\hline \multicolumn{5}{c}{ Rozloha kategórie HŠPK (ha) } \\
\hline Mapový podklad & $\begin{array}{c}\text { Dominancia } \\
\text { sadov }\end{array}$ & $\begin{array}{c}\text { Dominancia } \\
\text { TTP }\end{array}$ & $\begin{array}{c}\text { Mozaika polí } \\
\text { a TTP }\end{array}$ & $\begin{array}{c}\text { Mozaika polí, } \\
\text { TTP a sadov }\end{array}$ & Spolu \\
\hline TM G-K (1957) & 156,19 & 36,07 & 18,99 & 78,83 & 290,08 \\
ZM SR (1983) & 144,74 & 33,27 & 16,33 & 72,46 & 266,80 \\
DGO SR (2003) & 91,81 & 23,68 & 12,57 & 42,81 & 170,86 \\
ZBGIS (2007) & 89,36 & 23,31 & 11,42 & 40,98 & 165,07 \\
DO (2017) & 81,78 & 22,75 & 11,42 & 36,46 & 152,41 \\
\hline
\end{tabular}

\section{DISKUSIA}

Z pohl'adu plošného zastúpenia bol identifikovaný ako najpočetnejší subtyp HŠPK s dominanciou sadov, pričom značné zastúpenie bolo zaznamenané aj v prípade HŠPK s mozaikou ornej pôdy, TTP a sadov. Uvedené skutočnosti sú pravdepodobne spôsobené tým, že v území je dokumentovaný výrazný výskyt ovocných sadov, ktorých celková plošná rozloha dosahovala v roku 2017 takmer 10 \% z rozlohy záujmovej oblasti a taktiež fakt, že podiel pol'nohospodárskej pôdy na celkovej rozlohe územia dosahuje úroveň 56 \% (Moravčík 2019). Ovocné sady plnia najmä produkčnú funkciu. Vplyv na súčasný stav územia mala aj kolektivizácia, ktorej vrchol sa v tejto oblasti uskutočnil na prelome 70. a 80. rokov 20. storočia (Stankoviansky 2003), čomu by zodpovedal úbytok areálov HŠPK v období medzi rokmi 1957 až 2003, ked’že dynamika úbytkov dosiahla v rokoch 1957 - 1983 úro- 
veň 0,90 ha/rok, a v rokoch 1983 - 2003 až 4,80 ha/rok. Uvedené by mohlo byt' spôsobené postupným a menej výrazným priebehom kolektivizácie v 60. až 70 . rokoch 20. storočia - vznik JRD Stará Myjava a Brestovec v roku 1960 (Süle a Süle ml. 2005) s následným vzostupným trendom v 80. rokoch, pričom sa pravdepodobne prejavili aj d'alšie významné skutočnosti, ktoré mohli ovplyvnit' úbytok HŠPK, a to zmena politického režimu, resp. transformácia hospodárstva na trhovú ekonomiku a demografický vývoj vo forme postupného poklesu počtu obyvatel'ov od 70. rokov minulého storočia, emigrácie za prácou a s tým súvisiacim presunom obyvatel'ov do miest (Huba 1990). Dynamika úbytkov HŠPK v obdobiach rokov 2003 - 2007 a 2007 - 2017 dosiahla porovnatel'né hodnoty $(1,45$ ha/rok, resp. 1,27 ha/rok). Uvedené potvrdzuje skutočnost', ktorú uvádza aj Lieskovský et al. (2015), že implementácia Spoločnej pol’nohospodárskej politiky po vstupe Slovenska do EÚ mala len zanedbatel'ný vplyv na zachovanie tradičnej pol'nohospodárskej krajiny. Aj napriek týmto skutočnostiam je možné identifikovat' $v$ súčasnosti značné množstvo areálov HŠPK, čo môže byt' spôsobené tým, že kolektivizácia neprebehla na skúmanom území až tak výrazne a územie si zväčša zachovalo po nej typické črty (Pavličková 2007).

V prípade súvislosti výskytu areálov HŠPK so vzdialenost'ou od ekonomického centra oblasti môžeme konštatovat', že bol zaznamenaný menší pokles podielu areálov HŠPK v zónach, ktoré boli v menšej vzdialenosti od centra. Avšak pre definovanie všeobecne platných záverov je potrebné analyzovat' tento jav aj v iných lokalitách s výskytom roztrateného osídlenia. Solymosi (2011) uvádza, že väčšia vzdialenost' od miest môže mat' pozitívny vplyv na zachovanie historických štruktúr. Avšak Müller a Munroe (2008) a Baumann et al. (2011) tvrdia, že celkový vplyv vzdialenosti na zachovanie štruktúr je malý.

Výskumu HŠPK v rámci konkrétneho územia sa venovali aj Špulerová et al. (2017), a to v oblastiach Hriňová, Svätý Jur, Lednica a Liptovská Teplička. Slámová (2013) riešila lokality Budiná a Nižná Boca a Jančura a Bohálová (2017) oblast' Kysúc. Analýza zmien krajiny s výskytom roztrateného osídlenia v oblasti Ponitria bola realizovaná v práci Petroviča (2006). Jedinečnost' kopaničiarskeho regiónu Myjava spočíva aj v nadpriemernom výskyte subtypu HŠPK s dominanciou sadov, ked’že vo všetkých ostatných regiónoch s rozptýleným osídlením zväčša prevláda subtyp s dominantnými TTP, s výnimkou Trnavského regiónu, kde dominuje subtyp s mozaikou ornej pôdy, TTP a sadov (Špulerová et al. 2017).

\section{ZÁVER}

Príspevok sa zaoberá analýzou výskytu areálov HŠPK naviazaných na roztratené osídlenie vo vybranej časti kopaničiarskeho regiónu Myjava v období rokov 1957 až 2017. Celková rozloha areálov HŠPK klesla počas sledovaného obdobia z 290,08 ha na 152,41 ha. V záujmovom území dosiahli areály HŠPK v roku 2017 viac ako $12 \%$ podiel zo súhrnnej rozlohy pol'nohospodárskej pôdy. Jedinečnost' regiónu spočíva aj v tom, že najpočetnejší subtyp, v ktorom dominovali sady, zaznamenal percentuálny podiel v rámci rozlohy všetkých subtypov v rozmedzí 53 až $54 \%$. Najväčší úbytok areálov HŠPK nastal v období rokov 1983 až 2003 na úrovni 4,80 ha/rok. Priemerná rozloha záujmových areálov HŠPK dosiahla úbytok z hodnoty 5,45 ha na 3,03 ha. Vzdialenostná analýza nepreukázala, že by väčšia vzdialenost' od ekonomického centra mala pozitívny vplyv na zachovanie historických štruktúr. Dynamika úbytkov mala charakter procesov rozširovania zástavby 
(1957 až 2017), intenzifikácie pol'nohospodárstva (1957 až 2003) a extenzifikácie pol'nohospodárstva (1983 až 2017).

V rámci kopaničiarskeho regiónu Myjava nemala kolektivizácia pol'nohospodárstva $\mathrm{v}$ období socializmu až taký výrazný priebeh, pričom aj na základe tejto skutočnosti je jedinečnost' kopaničiarskeho regiónu, ktorá sa datuje už od 17. storočia (Pavličková 2007), v určitej forme zachovaná v súčasnosti, a to aj vd'aka prítomnosti areálov HŠPK.

Práca vznikla vd'aka podpore v rámci OP Výskum a vývoj pre dopytovoorientovaný projekt: Univerzitný vedecký park Univerzity Komenského v Bratislave, ITMS 26240220086, 2. Fáza ITMS 313021D075, spolufinancovaný zo zdrojov Európskeho fondu regionálneho rozvoja a v rámci projektu č. UK/144/2020 „,Vplyv zmien priestorovej štruktúry krajinnej pokrývky na globálne environmentálne riziká " poskytnutého Univerzitou Komenského v Bratislave.

\section{LITERATÚRA}

AGGER, P., BRANDT, J. (1988). Dynamics of small biotopes in Danish agricultural landscapes. Landscape Ecology, 1, 227-240. DOI: https://doi.org/10.1007/BF00157695.

AGNOLETTI, M. (2006). The development of a historical and cultural evaluation approach in landscape assessment: The dynamic of Tuscan landscape between 1832 and 2004. In Agnoletti, A., ed. The conservation of cultural landscapes. Wallingford, New York (CAB International), pp. 3-41. DOI: https://doi.org/10.1079/9781845930745.0003.

AGNOlETTI, M., CARGNELlO, G., GARDIN, L., SANTORO, A., BAZZOFFI, P., SANSONE, L., PEZZA, L., BELFIORE, N. (2011). Traditional landscape and rural development: Comparative study in three terraced areas in northern, central and southern Italy to evaluate the efficacy of GAEC standard 4.4 of cross compliance. Italian Journal of Agronomy, 6, 121-139. DOI: https://doi.org/10.4081/ija.2011.6.s1.e16.

AGNOLETTI, M. (2013). Italian historical rural landscapes. Cultural values for the environment and rural development. Dordrecht (Springer). DOI: https://doi.org/ 10.1007/978-94-007-5354-9.

BAUMANN, M., KUEMMERLE, T., ELBAKIDZE, M., OZDOGAN, M., RADELOFF, V. C., KEULER, N. S., PRISHCHEPOV, A. V., KRUHLOV, I., HOSTERT, P. (2011). Patterns and drivers of post-socialist farmland abandonment in Western Ukraine. Land Use Policy, 28, 552-562. DOI: https://doi.org/10.1016/j.landusepol.2010.11.003.

BRŮNA, V., BUCHTA, I., UHLÍROVÁ, L. (2002). Identifikace historické sitě prvků ekologické stability krajiny na mapách vojenských mapování. Ústí nad Labem (Univerzita J. E. Purkyně).

CAJTHAML, J. (2013). Old maps georeferencing - overview and a new method for map series. In Buchroithner, M. F., ed. 26th International Cartographic Conference Proceedings. Dresden (International Cartographic Association).

CAJTHAML, J., KREJČÍ, J. (2008). Využití starých map pro výzkum krajiny. In Pešková, K., ed. Zborník zo sympózia „, GIS Ostrava 2008 - 15 rokov v geoinformatike“. Ostrava (VŠB-TU Ostrava), pp. 1-10.

CREWS-MEYER, K. A. (2004). Agricultural landscape change and stability in northeast Thailand: Historical patch-level analysis. Agriculture, Ecosystems \& Environment, 101, 155-169. DOI: https://doi.org/10.1016/j.agee.2003.09.024.

ČERŇANSKÝ, J., KOŽUCH, M. (2004). Využitie ortofotomáp na tvorbu GIS. Pedagogické listy, 11, 21-28.

ČERŇANSKY, J., KOŽUCH, M., STANKOVÁ, H. (2003). Sledovanie a hodnotenie zmien vysokohorskej krajiny s využitím ortofotomáp. In Čižmár, J., Čuláková, K., eds. 
Geoinformatizácia kartografie - Zbornik z 15. kartografickej konferencie s medzinárodnou účast’ou, Zvolen, 4. - 5. 9. 2003, Bratislava (Kartografická spoločnost' SR), pp. 93-101.

DOBROVODSKÁ, M., ŠPULEROVÁ, J., ŠTEFUNKOVÁ, D. (2014). Metodika mapovania historických štruktúr pol'nohospodárskej krajiny Slovenska a návrhu ich optimálneho manažmentu. Životné prostredie, 48, 209-212.

FALŤAN, V., OŤAHEL', J., GÁBOR, M., RUŽEK, I. (2018). Metódy výskumu krajinnej pokrývky. Bratislava (Univerzita Komenského v Bratislave).

GEODIS SLOVAKIA, EUROSENSE (2005). Ortofotomapa (C) Geodis Slovakia, s. r. o., Banská Bystrica. Letecké snímkovanie a Digitálna ortofotomapa (C) Eurosense s. r. o., Bratislava.

HANUŠIN, J., LACIKA, J. (2018). Vybrané environmentálne súvislosti zmien historickej lazníckej krajiny (na príklade obce Hrušov okres Vel'ký Krtíš). Geografický časopis, 70, 57-77. DOI: https://doi.org/10.31577/geogrcas.2018.70.1.04.

HUBA, M., ed. (1988). Historické krajinné štruktúry. (Ochranca prírody, odborná príloha spravodaja Mv SZoPK). Bratislava (MV).

HUBA, M. (1989). O niektorých otázkach genézy a súčasného stavu kopaničiarskeho osídlenia na území Slovenskej socialistickej republiky. Geografický časopis, 41, 138-155.

HUBA, M (1990). O perspektívach kopaničiarskeho osídlenia a kopaničiarskej krajiny na území Slovenskej republiky. Geografický časopis, 42, 113-130.

HUBA, M. (1997). Kopaničiarske osídlenie, životné prostredie a trvalo udržatel'ný spôsob existencie. Životné prostredie, 31, 61-66.

HUBA, M. (2004). Historické štruktúry krajiny v kontexte súčasnej reality. Životné prostredie, 38, 86-89.

HUSÁR, K. (1996). Presnost' digitálnych priestorových údajov. Kartografické listy, 4, 69-78.

JANČURA, P., BOHÁLOVÁ, I. (2017). Historické krajinné štruktúry Kysúc (Fragmenty histórie). Forum Historiae, 11, 37-51.

KAŇUK, J., GALLAY, M., HOFIERKA, J. (2015). Generating time series of virtual 3-D city models using a retrospective approach. Landscape and Urban Planning, 139, 40-53. DOI: https://doi.org/10.1016/j.landurbplan.2015.02.015.

LAUKO, V. (1985). Vývoj a transformácia kopaničiarskeho osídlenia Myjavskej pahorkatiny. Acta Facultatis Rerum Naturalium Universitalis Comenianae, Geographica, 25, 3552.

LAUKO, V. (1990). Socioekonomický vývoj a charakteristika kopaničiarskeho regiónu Myjavskej pahorkatiny. Acta Facultatis Rerum Naturalium Universitatis Comenianae. Geographica, 28, 207-223.

LAUKO, V. (1999). Transformačné zmeny v regióne roztrateného osídlenia na príklade Myjavy. Folia Geographica, 3, 269-276.

LAUKO, V., NEMČEK, P. (1998). Aktuálne zmeny v populačnom vývoji kopaničiarskeho regiónu Myjavy. Acta Facultatis Rerum Naturalium Universitatis Comenianae. Geographica, 41, 123-135.

LIESKOVSKÝ, J., BEZÁK, P., ŠPULEROVÁ, J., LIESKOVSKÝ, T., KOLEDA, P., DOBROVODSKÁ, M., BÜRGI, M., GIMMI, U. (2015). The abandonment of traditional agricultural landscape in Slovakia - Analysis of extent and driving forces. Journal of Rural Studies, 37, 75-84. DOI: https://doi.org/10.1016/j.jrurstud.2014.12.007.

MIČIETOVÁ, E., KOŽUCH, M. (2008). Špecializované informačné technológie $v$ prírodovednom výskume: Geoinformačné technológie. Bratislava (Elita).

MORAVČÍK, F. (2019). Zmeny priestorovej štruktúry krajinnej pokrývky vybranej časti kopaničiarskeho regiónu Myjavy. Diplomová práca, Prírodovedecká fakulta Univerzity Komenského v Bratislave, Bratislava.

MORAVČÍK, F., BENOVÁ, A. (2020). Analýza výskytu vybraných krajinných prvkov v časti kopaničiarskeho regiónu Myjava. Kartografické listy, 28, 15-29. 
MÜLLER, D., MUNROE, D. K. (2008). Changing rural landscapes in Albania: Cropland abandonment and forest clearing in the postsocialist transition. Annals of the Association of American Geographers, 98, 855-876. DOI: https://doi.org/10.1080/ 00045600802262323.

PAVLIČKOVÁ, K. (2007). Analýza rozvoja myjavských kopaníc na základe vývoja využitia zeme. Acta Environmentalica Universitatis Comenianae, 15, 83-93.

PETROVIČ, F. (2002a). Rozptýlené osídlenie Novobanskej štálovej oblasti ajeho vplyv na rozvoj regiónu. In Drgoňa, V., Kramáreková, H., eds. Geographical Informations, No. 7 , II. Nitra (FPV UKF), pp. 152-156.

PETROVIČ, F. (2002b). Zmeny využívania domového fondu štálového osídlenia v pohoriach Tribeč a Pohronský Inovec. Rosalia (Nitra), 16, 217-222.

PETROVIČ, F. (2005). Vývoj krajiny v oblasti štálového osídlenia Pohronského Inovca a Tribeča. Bratislava (Ústav krajinnej ekológie SAV).

PETROVIČ, F. (2006). Changes of the landscape with dispersed settlement. Ekológia (Bratislava), Supplement 1, 25, 201-211.

SAZZP (2020). WMS Slovenskej agentúry životného prostredia. Bratislava (Slovenská agentúra životného prostredia), [Online]. Dostupné na: http://nipi.sazp.sk/arcgis/services/ng/ rastre/MapServer/WMSServer [cit. 10-02-2020].

SERENI, E. (1997). History of the Italian agricultural landscape. Princeton (Princeton University Press).

SLÁMOVÁ, M. (2013). Význam identifikácie historických krajinných štruktúr v krajinných typoch Slovenska. Zvolen (Technická univerzita vo Zvolene).

SLÁMOVÁ, M., JANČURA, P., DANIŠ, D. (2013). Methods of historical landscape structures identification and implementation into landscape studies. Ekológia, 32, 267-276.

SOLYMOSI, K. (2011). Indicators for the identification of cultural landscape hotspots in Europe. Landscape Research, 36, 3-18. DOI: https://doi.org/10.1080/01426397. 2010.530647.

SPIŠIAK, P. (1998). Vývoj obyvatel'stva v kopaničiarskom osídlení Slovenska. Geografické informácie, 5, 18-25.

SPOONER, P. G., LUNT, I. D., BRIGGS, S. V. (2004). Spatial analysis of anthropogenic disturbance regimes and roadside shrubs in a fragmented agricultural landscape. Applied Vegetation Science, 7, 61-70. DOI: https://doi.org/10.1111/j.1654-109X. 2004.tb00596.x.

SSGK (1972). Základná mapa ČSSR 1:10 000, Zoznam mapových značiek (Príloha 1 k Smerniciam pre tvorbu základnej mapy ČSSR 1:10 000). Bratislava (Slovenská správa geodézie a kartografie).

STANKOVÁ, H. (2007). Návrh legendy pre mapovanie krajinnej pokrývky vysokých pohorí využitím digitálnych ortofotomáp. In Fencík, R., ed. Súčasné trendy v kartografii. Zborník zo 17. kartografickej konferencie. Bratislava (STU), pp. 184-189.

STANKOVIANSKY, M. (2003). Geomorfologická odozva environmentálnych zmien na území Myjavskej pahorkatiny. Bratislava (Univerzita Komenského v Bratislave).

ŠPULEROVÁ, J., DOBROVODSKÁ, M., LIESKOVSKÝ, J., BAČA, A. (2012). Typizácia historických štruktúr pol'nohospodárskej krajiny na Slovensku. Životné prostredie, 46, 3-10.

ŠPULEROVÁ, J., PETROVIČ, F. (2011). Historical agricultural landscape as a subject of landscape ecological research. Hrvatski Geografski Glasnik, 73, 155-163. DOI: https:// doi.org/10.21861/hgg.2011.73.02.11.

ŠPULEROVÁ, J., ŠTEFUNKOVÁ, D., DOBROVODSKÁ, M. et al. (2017). Historické štruktúry pol'nohospodárskej krajiny Slovenska. Bratislava (Veda).

SÜLE, P., SÜLE, P. ml., eds. (2005). Encyklopédia miest a obci Slovenska. Lučenec (PS-LINE).

ÚGKK SR (2007). Základná báza údajov pre geografický informačný systém. Bratislava (Úrad geodézie, kartografie a katastra Slovenskej republiky). 
ÚGKK SR (2020). Ortofotomozaika WMTS. Bratislava (Úrad geodézie, kartografie a katastra Slovenskej republiky), [Online]. Dostupné na: https://zbgisws.skgeodesy.sk/ zbgis ortofoto wmts/service.svc/get? [cit. 23-02-2020].

ÚSGK (1959). Dohodnuté značky topografických máp v mierkach 1:10 000 a 1:5 000 (Slovenské znenie), druhé, pozmenené vydanie. Praha (Ústredná správa geodézie a kartografie).

VOJTKO, R., REICHWALDER P. (2016). Interpretácia leteckých a kozmických snimok $v$ geológii. Vysokoškolské skriptá. Bratislava (Prírodovedecká fakulta Univerzity Komenského).

Filip Moravčik, Alexandra B e nová

\section{DYNAMICS OF HISTORICAL STRUCTURES OF AGRICULTURAL LANDSCAPE, CASE STUDY: PART OF THE SCATTERED SETTLEMENT OF MYJAVA REGION}

The paper deals with the occurrence of subtypes of historical structures of agricultural ladnscape (HSAL) within a selected part of the Myjava region (Fig. 1). Attention is also paid to the impact of various socio-economic events (collectivization of agriculture, establishment of the Slovak Republic, implementation of the common agricultural policy) and the analysis of the distance from the city of Myjava. Five different map sources were used covering the period from 1957 to 2017 from the newet to the oldest: digital orthophotomosaic - DO, year 2017 (Fig. 6); Slovak state database for the geographic information system - ZBGIS, year 2007 (Fig. 5); digital orthophotomap of the Slovak Republic - DGO SR, year 2033 (Fig, 4), Basic map of Slovak Republic - ZM SR, year 1983 (Fig. 3), Military topographic map in the Gauss-Krüger projection - TM G-K, year 1957 (Fig. 2). The method of retrospective comparison of the individually interpreted maps from the newest to oldest was used for analysis of occurrence HSAL.

Four subtypes of HSAL were identified on each map source, namely: subtype with dominance of orchards, subtype with dominance of permanent grasslands, subtype with mosaic of fields and permanent grasslands, subtype with mosaic of fields, and permanent grasslands and orchards. The total area of HSAL decreased during the monitored period from 290.08 hectares to 152.41 hectares (Fig. 7). In the area of interest, the HSAL reached more than $12 \%$ of the total area of agricultural land. The most numerous subtype was the subtype with a dominance of orchards - recorded a percentage within the area of all subtypes ranging from 53 to $54 \%$. The largest decrease in HSAL areas occurred in the period from 1983 to 2003 and reached the value of 4.80 hectares/year (Fig. 8). Based on the distance analysis, a decrease in the percentage of HSAL areas in zones that were at a greater distance (above $5 \mathrm{~km}$ ) from the district town of Myjava was recorded (Tab. 1). The decrease also occurred in the average area of HSAL areas: from 5.45 hectares to 3.03 hectares (Tab. 2). The processes of intensification of agriculture, extensification of agriculture and expanding the build-up areas was recorded in the dynamics of declines.

HSAL represent the specific landscape structures that significantly affect the increase of biodiversity of the area (Spulerová et al. 2017). Within the Myjava region with a scattered settlement, the collectivization of agriculture in the period of socialism did not have such a significant impact. Thanks to this, the uniqueness of the region with historical structures of cultural landscape, which dates back to the $17^{\text {th }}$ century (Pavličková 2007), is preserved to certain extent until today, also due to the presence of HSAL areas. 
